\title{
Thyroid status modulates \\ T Iymphoma growth via cell cycle regulatory proteins and angiogenesis
}

\author{
H A Sterle', E Valli', F Cayrol', M A Paulazo ${ }^{1}$, D J Martinel Lamas ${ }^{3}$, M C Diaz Flaqué', \\ A J Klecha ${ }^{3}$, L Colombo ${ }^{4}$, V A Medina ${ }^{3}$, G A Cremaschi ${ }^{1,3}$ and M L Barreiro Arcos ${ }^{1,5}$ \\ ${ }^{1}$ Instituto de Investigaciones Biomédicas (BIOMED), Consejo Nacional de Investigaciones Científicas y Técnicas \\ (CONICET), Facultad de Ciencias Médicas, Pontificia Universidad Católica Argentina (UCA), Av. A. Moreau de \\ Justo 1600, 3er piso, 1107AFF Buenos Aires, Argentina \\ ${ }^{2}$ Centro de Estudios Farmacológicos y Botánicos (CEFYBO), CONICET, Facultad de Medicina, Universidad de Buenos \\ Aires (UBA), Buenos Aires, Argentina \\ ${ }^{3}$ Laboratorio de Radioisótopos, Facultad de Farmacia y Bioquímica, Universidad de Buenos Aires (UBA), \\ Buenos Aires, Argentina \\ ${ }^{4}$ Area de Investigación, Instituto de Oncología 'Angel H. Roffo', Universidad de Buenos Aires (UBA), \\ CONICET, Buenos Aires, Argentina \\ ${ }^{5}$ Departamento de Química Biológica, Facultad de Ciencias Exactas y Naturales, Universidad de Buenos Aires (UBA), \\ Buenos Aires, Argentina
}

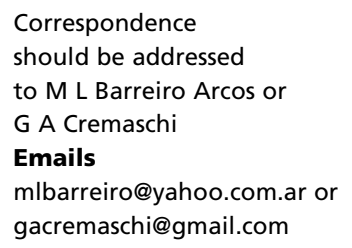

\begin{abstract}
We have shown in vitro that thyroid hormones (THs) regulate the balance between proliferation and apoptosis of T lymphoma cells. The effects of THs on tumor development have been studied, but the results are still controversial. Herein, we show the modulatory action of thyroid status on the in vivo growth of T lymphoma cells. For this purpose, euthyroid, hypothyroid, and hyperthyroid mice received inoculations of EL4 cells to allow the development of solid tumors. Tumors in the hyperthyroid animals exhibited a higher growth rate, as evidenced by the early appearance of palpable solid tumors and the increased tumor volume. These results are consistent with the rate of cell division determined by staining tumor cells with carboxyfluorescein succinimidyl ester. Additionally, hyperthyroid mice exhibited reduced survival. Hypothyroid mice did not differ significantly from the euthyroid controls with respect to these parameters. Additionally, only tumors from hyperthyroid animals had increased expression levels of proliferating cell nuclear antigen and active caspase 3. Differential expression of cell cycle regulatory proteins was also observed. The levels of cyclins D1 and D3 were augmented in the tumors of the hyperthyroid animals, whereas the cell cycle inhibitors p16/INK4A (CDKN2A) and p27/Kip1 (CDKN1B) and the tumor suppressor p53 (TRP53) were increased in hypothyroid mice. Intratumoral and peritumoral vasculogenesis was increased only in hyperthyroid mice. Therefore, we propose that the thyroid status modulates the in vivo growth of EL4 T lymphoma through the regulation of cyclin, cyclin-dependent kinase inhibitor, and tumor suppressor gene expression, as well as the stimulation of angiogenesis.
\end{abstract}

\section{Key Words}

- thyroid hormones

- T lymphoma

- cell cycle

- angiogenesis
Journal of Endocrinology (2014) 222, 243-255 http://joe.endocrinology-journals.org DOI: 10.1530/JOE-14-0159
() 2014 Society for Endocrinology Printed in Great Britain
Published by Bioscientifica Ltd 


\section{Introduction}

Thyroid hormones (THs) exert a wide variety of effects on lymphocyte function and their regulatory effects on tumor processes have also been described. Thus, alterations of the thyroid axis during the course of neoplastic illness, as well as the actions of THs on tumor growth, have been suggested. However, the effect of thyroid status on the evolution of tumors is controversial, and the mechanisms involved remain unknown. It has been reported that hypothyroidism can be a risk factor for the development of liver and breast cancer in humans (Reddy et al. 2007). Moreover, the use of levothyroxine, a synthetic $\mathrm{T}_{4}$ hormone commonly used to treat thyroid disease, was associated with a significantly reduced risk of colorectal cancer (Rennert et al. 2010). However, it was also shown that hypothyroid patients have a lower incidence of mammary carcinoma (Cristofanilli et al. 2005), and deprivation of THs decreased the growth rates of solid tumors, while TH supplementation increased it (Guernsey et al. 1980, Hercbergs et al. 2010). Prospective studies to date have also yielded conflicting results. In fact, several studies have indicated that subclinical hyperthyroidism increases the risk of certain solid tumors, but spontaneous hypothyroidism delays the onset and reduces the aggressiveness of cancers (Hercbergs et al. 2010). However, a recent meta-analysis showed no association between hypothyroidism and an increased risk of breast cancer (Angelousi et al. 2012). Thus, the heterogeneity of the analyzed studies precludes firm conclusions. MartínezIglesias et al. (2009) showed that hypothyroidism resulted in a decreased rate of solid tumor growth, as well as an increase in the development and number of metastases, in murine xenograft models of human hepatocarcinoma and breast cancer. However, low levels of circulating THs, induced by stress, enhanced tumor progression in mice, an effect that was reversed following $\mathrm{T}_{4}$ administration (Frick et al. 2009a,b). Through in vitro studies, we have demonstrated that culturing T lymphoma cells for $24-72 \mathrm{~h}$ in the presence of THs increased cell proliferation via the activation of intracellular growth-related signaling pathways (Barreiro Arcos et al. 2006, 2011). However, long-term exposure to $T_{4}$ (15 days of culture or more) leads to T lymphoma cell apoptosis (Mihara et al. 1999, Barreiro Arcos et al. 2013).

Cell cycle regulatory proteins such as cyclins, cyclindependent kinases (CDKs), CDK inhibitors (CDKIs), and tumor suppressor proteins play important roles in tumor growth and progression. The expression of cyclins D1, D2, and D3 is required for the progression from G0 phase to G1 phase, cyclin E2 is necessary for G1 to $S$ phase transition and cyclin B1 for G2 to M transition. These cyclins bind to their corresponding CDKs to form active complexes that induce the expression of a large number of cell cycle regulatory genes. Additionally, tumor suppressor genes inhibit cyclin-CDK complexes leading to cell cycle arrest.

Both TH-mediated up- and down-regulation of cyclins have been demonstrated in several tissues (Ledda-Columbano et al. 2005, Chattergoon et al. 2007, Verga Falzacappa et al. 2012). TH-mediated regulation of cyclin-CDK complexes leading to cell arrest (Toms et al. 1998) or cell differentiation (Ballock et al. 2000) has also been demonstrated.

Alisi et al. (2005) showed in vivo that hyperthyroidism increases the levels of cyclins D1, E, and A and the activity of cyclin-CDK complexes, and decreases the levels of CDKIs, such as p16/INK4A (CDKN2A) and p27/KIP1 (CDKN1B). They also demonstrated that hypothyroidism induces contrary effects and that THs modulate the expression of the tumor suppressor genes $p 53$ (Trp53) and $p 73$ (Trp73), both involved in apoptosis and growth arrest. Hence the possibility that thyroid status influences tumor growth by altering the expression of cyclin, CDKs, CDKIs, or tumor suppressor genes deserves to be explored.

The development of solid tumors requires the formation of new blood vessels. Numerous studies have demonstrated that the thyroid status modulates angiogenesis, but the results of these studies are controversial. Kucharz et al. (2003) demonstrated that increased or decreased levels of endostatin, a natural inhibitor of angiogenesis, were associated with hyperthyroidism and hypothyroidism respectively. Additionally, increased serum levels of angiogenic molecules were found in autoimmune thyroid diseases (Figueroa-Vega et al. 2009). The recent description of a plasma membrane receptor for THs that could mediate the proliferative action of the hormone in blood vessels and tumor cells could shed some light on this matter (Cheng et al. 2010).

Based on this background, the aim of this work was to study the effects of thyroid status on T cell lymphoma growth in vivo in euthyroid, hyperthyroid, or hypothyroid syngeneic mice, thus deepening our understanding of the mechanisms involved in TH action, particularly those related to cell cycle progression and tumor angiogenesis.

\section{Materials and methods}

\section{Animal models}

Inbred female $\mathrm{C} 57 \mathrm{BL} / 6 \mathrm{~J}\left(\mathrm{H}-2^{\mathrm{b}}\right)$ mice, 2-3 months old, were bred and kept at the Instituto de Investigaciones

Published by Bioscientifica Ltd. 
Biomédicas (BIOMED, CONICET-UCA, Buenos Aires, Argentina) in accordance with the ARRIVE Guidelines (Kilkenny et al. 2010). All experimental protocols were approved by the Institutional Committee for the Care and Use of Laboratory Animals of the School of Medicine. Animals were kept in a $12 \mathrm{~h}$ light: $12 \mathrm{~h}$ darkness cycle with a controlled temperature between 18 and $22^{\circ} \mathrm{C}$, with access to food and water and were allowed to feed ad libitum.

Models of hyperthyroidism or hypothyroidism were developed in accordance with the protocol of Klecha et al. (2005, 2006). Briefly, hyperthyroidism was achieved by daily treatment with $0.012 \mu \mathrm{g} / \mathrm{ml} \mathrm{T}_{4}$ (Sigma-Aldrich) in drinking water for 1 month and hypothyroidism by similar treatment with $0.5 \mu \mathrm{g} / \mathrm{ml}$ propylthiouracil (PTU; Sigma-Aldrich) for 15 days.

\section{Hormone determinations}

Blood was collected from the tail vein using a capillary tube coated with anticoagulant and plasma was obtained by centrifugation. The plasma levels of tri-iodothyronine $\left(T_{3}\right)$ and $T_{4}$ were determined using commercial RIA kits with specific antibodies (Immunotech, Praga, Czech Republic) according to the manufacturer's instructions. The plasma TSH level was assayed using an ELISA kit (Uscn Life Science, Inc., Wuhan, Hubei, Republic of China).

\section{Lymphoma model}

The tumor cell line EL4 (ATCC, Manassas, VA, USA; Catalog Number TIB-39), a mouse T-cell lymphoma expressing the $\mathrm{H}-2^{\mathrm{b}}$ and Thy-1.2 haplotype, as well as the $\mathrm{CD}^{+}$and $\alpha \beta \mathrm{T}$ cell receptors; was routinely tested by flow cytometry with specific antibodies against the corresponding surface markers. These cells were cultured at an optimal concentration $\left(1-5 \times 10^{5}\right.$ cells $\left./ \mathrm{ml}\right)$ in RPMI-1640 medium supplemented with $10 \% \mathrm{v} / \mathrm{v}$ fetal bovine serum, $2 \mathrm{mmol} / \mathrm{l}$ glutamine, and $100 \mathrm{mg} / \mathrm{ml}$ streptomycin (all from Life Technologies). Euthyroid, hyperthyroid, or hypothyroid C57BL/6J syngeneic animals received subcutaneous injections of $3 \times 10^{5}$ EL4 cells in $200 \mu$ PBS to generate a solid tumor. After cell inoculation, hormonal treatments were maintained until the end of the experiments.

\section{Tumor development}

Tumor length and width were measured daily using calipers. Tumor volume was calculated by the equation $\mathrm{V}=(\pi / 6) \times$ length $\times$ width $^{2}$ (Frick et al. 2011). The rate of tumor growth was quantified by carboxyfluorescein succinimidyl ester (CFSE) staining (Vybrant CFDA SE Cell Tracer Kit, Life Technologies; Lyons 1999). Cells were labeled as described previously (Barreiro Arcos et al. 2006). The stained cells $\left(3 \times 10^{5}\right.$ cells $\left./ 0.2 \mathrm{ml} \mathrm{PBS}\right)$ were used to subcutaneously inoculate C57BL/6J mice with different thyroid status. After 10 days, mice were killed, and the solid tumors were extracted and dispersed in a metal mesh. The tumor cell suspensions were fixed in $3.7 \% \mathrm{v} / \mathrm{v}$ formaldehyde and analyzed by flow cytometry (FACSCalibur, BD, San Jose, CA, USA) at $492 \mathrm{~nm}$. The estimated cell division time was calculated from the mean fluorescence intensity (MFI) values of EL4 cells using the following equation: $T_{1 / 2}=(k \times$ time post-inoculation)/ $\ln T-\ln T_{0}$, where $T_{1 / 2}$ is the cell doubling time, $k$ is the constant of value $0.693, T$ is the MFI of the CFSE quantified at ten days post-inoculation, and $T_{0}$ is the MFI of the CFSE of EL4 cells before inoculation (Frick et al. 2009a,b).

Animal survival analysis was performed using Kaplan-Meier curves. Briefly, mice were monitored every day and killed according to the guidelines for animal care when they showed signs of suffering, hypothermia, and slow locomotion, which is characteristic of animals that are about to die (Massari et al. 2013). All animals had approximately the same tumor burden, without metastatic dissemination when killed.

\section{Tumor histopathology}

Solid tumors growing in euthyroid, hyperthyroid, and hypothyroid mice were excised and fixed in $3.7 \% \mathrm{v} / \mathrm{v}$ formaldehyde overnight. Then, the samples were embedded in paraffin and cut into $4 \mu \mathrm{m}$ thick serial sections using a microtome. Tumor morphology and histopathological characteristics were examined after hematoxylin-eosin (H\&E) and Masson's trichrome staining. The number of mitotic cells was quantified as the number of cells with visible chromosomes in $630 \times$ magnification fields. Vascularization was determined using Masson's trichrome staining, and the stained sections were screened at $50 \times$ magnification to identify the largest vascular areas around the tumor. In these areas, intratumoral vascularity was evaluated by counting the vessels in ten random fields from inside the tumor at $630 \times$ magnification. Light microscopy was performed using an Axiolab Karl Zeiss microscope (Göttingen, Germany). Photographs were taken at $630 \times$ magnifications using a Canon PowerShot G5 camera (Tokyo, Japan). Intratumoral vascularization was also analyzed by immunohistochemistry.

Published by Bioscientifica Ltd. 


\section{Immunohistochemistry}

Cell proliferation, apoptosis, and angiogenesis markers were examined by immunohistochemistry of tumor tissue sections, prepared as described previously. Antigen retrieval was performed in citrate buffer $(10 \mathrm{mmol} / \mathrm{l}, \mathrm{pH} 6.0)$ at $100{ }^{\circ} \mathrm{C}$, and endogenous peroxidase activity was blocked with $3 \% \mathrm{v} / \mathrm{v} \mathrm{H}_{2} \mathrm{O}_{2}$ in distilled water. After blocking, the tissues were incubated with the following primary antibodies overnight in a humidified chamber at $4{ }^{\circ} \mathrm{C}$ : mouse anti-proliferating cell nuclear antigen (PCNA, 1:100, Santa Cruz Biotechnology, Inc.), rabbit anti-cleaved caspase 3 (1:100, Abcam, Cambridge, MA, USA), and rabbit antiCD31 (1:200, Abcam). Immunoreactivity was detected using HRP-conjugated anti-mouse or anti-rabbit antibodies and was visualized by diaminobenzidine staining (SigmaAldrich). Serial sections from selected positive cases were used as controls, by replacing the primary antibody with either a normal mouse or rabbit IgG or PBS in the staining procedure. No signal was detected in these control samples.

\section{Angiogenesis}

EL4 cells $\left(3 \times 10^{5}\right)$ were subcutaneously inoculated into the left flank of euthyroid, hyperthyroid, and hypothyroid mice. On day 6, when the tumors were palpable in the three groups, mice were killed, and the blood vessels supplying the tumor were quantified by microscopy, as described previously by Ferrando et al. (2011). It is worth noting that it is not possible to accurately evaluate peritumoral angiogenesis at day 10, because of the large size of the tumor mass. To evaluate the level of angiogenesis associated with the tumor, the number of blood vessels in the tumor tissue area was normalized to the number of vessels in the normal dermal tissue area present in the right flank (control), which had received an injection of sterile PBS solution.

\section{RT and real-time quantitative PCR (qPCR)}

After the animals were killed, solid tumors were removed and immediately homogenized in Tri-Reagent (Genbiotech SRL, Buenos Aires, Argentina) to isolate the RNA, according to the manufacturer's instructions. The RNA pellets were dissolved in RNase-free water and the RNA concentration was quantified by measuring the absorbance at $260 \mathrm{~nm}$ (Nanodrop ND-1000, Thermo Fisher Scientific Inc., Wilmington, DE, USA). cDNA was synthesized by retrotranscription using the Omniscript kit (Qiagen) following the manufacturer's instructions using $2 \mu \mathrm{g}$ total RNA and $1 \mu \mathrm{mol} / \mathrm{l}$ oligodeoxythymidine $_{12-18}$ (Biodynamics SRL, Buenos Aires,
Table 1 Primer sequences used for real-time RT-PCR analysis. The primers were designed using the mouse CDNA sequences in the UniGene database, following the criteria established by the Primer Express Software (Applied Biosystems)

\begin{tabular}{|c|c|c|}
\hline Gene & Primer sequences & $T_{\mathbf{m}}\left({ }^{\circ} \mathrm{C}\right)$ \\
\hline Cyclin A2 & $5^{\prime}$-GGCCAGCTGAGCTTAAAGA & 58.3 \\
\hline (Ccna2) & $5^{\prime}$-CGGGTAAAGAGACAGCTGCAT-3' & 58.1 \\
\hline Cyclin B1 & 5'-AGGGTCGTGAAGTGACTGGAAACA-3' & 60.2 \\
\hline$(C c n b 1)$ & 5'-CTTGGGCACACAACTGTTCTGCAT-3' & 60.3 \\
\hline Cyclin D1 & 5'-CCAAAACCATTCCATTTCAAAG-3' & 57.2 \\
\hline (Ccnd1) & 5'-CCAACACACACCAGCAACACT-3' & 58.1 \\
\hline Cyclin D2 & 5'-ACTTCAAGTTTGCCATGTACCCGC-3' & 60.1 \\
\hline$(C \mathrm{cnd} 2)$ & 5'-TTCAGCAGCAGAGCTTCGATTTGC-3' & 60.2 \\
\hline Cyclin D3 & $5^{\prime}$-TGCGTGCAAAAGGAGATCAA-3' & 59.0 \\
\hline (Ccnd3) & $5^{\prime}$-TCACACACCTCCAGCATCCA-3' & 59.7 \\
\hline Cyclin E1 & 5'-TGCTACTTGACCCACTGGACTCT-3' & 58.9 \\
\hline (Ccne1) & $5^{\prime}-\mathrm{TGGCC}$ & 58.2 \\
\hline \multirow[t]{2}{*}{$p 15 / I n k 4 b$} & 5'-TGGGAAACCTGGAGAGTAGATGA-3' & 58.7 \\
\hline & 5'-GAATCCCCACACATGACAGTACA-3' & 58.3 \\
\hline \multirow[t]{2}{*}{ p16/Ink4a } & 5'-CTCAACTACGGTGCAGATTCGA-3' & 59.0 \\
\hline & $5^{\prime}$-CACCGGGCGGGAGAA-3' & 58.5 \\
\hline \multirow[t]{2}{*}{ p21/Cip1 } & 5'-TGTGGCTCCCTCCCTGTCT-3' & 59.2 \\
\hline & $5^{\prime}-\mathrm{GCA}$ & 58.8 \\
\hline \multirow[t]{2}{*}{ p27/Kip1 } & 5'-CCTGGCTCTGCTCCATTTGA-3' & 59.9 \\
\hline & $5^{\prime}$-ACGGATGGAGCGCAAAAC-3' & 58.2 \\
\hline \multirow[t]{2}{*}{$p 53$} & 5'-GCATCCCGTCCCCATCA-3' & 59.8 \\
\hline & 5'-GGATTGTGTCTCAGCCCTGAA-3' & 58.7 \\
\hline \multirow[t]{2}{*}{$R b$} & $5^{\prime}$-GGTCTGCCAACACCCACAA-3' & 58.9 \\
\hline & 5'-GATGTCCCAAATGATTCACCAA-3 & 58.2 \\
\hline \multirow[t]{2}{*}{ Pten } & 5'-GGTTCTTGGAAAACGGTGCTTAT-3' & 59.4 \\
\hline & 5'-TGAAACCTCCCATGTGCTGAT-3' & 59.0 \\
\hline \multirow{2}{*}{$\begin{array}{c}\beta_{2} \text { micro- } \\
\text { globulin } \\
(B 2 m)\end{array}$} & 5'-GCTATCCAGAAAACCCCTCAA-3' & 62.0 \\
\hline & 5'-CATGTCTCGATCCCAGTAGACGG1 & \\
\hline
\end{tabular}

Argentina). PCRs were performed using a commercial master mix for Real-Time PCR containing SYBR Green fluorescent dye (Biodynamics SRL) in a total volume of $25 \mu \mathrm{l}$, which contained $10 \mathrm{pmol}$ of each primer and $1 \mu \mathrm{l}$ of cDNA. The reactions were carried out in a Rotor Gene-6000 DNA thermal cycler (Corbett, Life Sciences, Sydney, Australia). The cycling conditions were $95^{\circ} \mathrm{C}$ for $15 \mathrm{~min}$, followed by 40 cycles of denaturation at $95^{\circ} \mathrm{C}$ for $10 \mathrm{~s}$, annealing at $60^{\circ} \mathrm{C}$ for $15 \mathrm{~s}$, and extension at $72{ }^{\circ} \mathrm{C}$ for $30 \mathrm{~s}$. The primer sequences (Biodynamics SRL), shown in Table 1, were designed using the Primer Express Software version 3.0 (Applied Biosystems). Quantification of the target gene expression was performed using the comparative cycle threshold $\left(C_{\mathrm{t}}\right)$ method (Livak \& Schmittgen 2001). An average $C_{\mathrm{t}}$ value was calculated from the duplicate reactions and normalized to the expression of $\beta_{2}$-microglobulin, and the $\Delta \Delta C_{t}$ value was then calculated.

\section{Immunoblot analysis}

The tumor mass was excised and tissue cells were dissected in a metal mesh. The tumor cells were lysed for $30 \mathrm{~min}$ at

Published by Bioscientifica Ltd 
$4{ }^{\circ} \mathrm{C}$ in lysis buffer (Barreiro Arcos et al. 2013). After centrifugation at $14000 \mathrm{~g}$ for $15 \mathrm{~min}$ at $4^{\circ} \mathrm{C}$, whole-cell protein extracts obtained $(30 \mu \mathrm{g})$ were separated by SDSPAGE on $10 \% \mathrm{v} / \mathrm{v}$ polyacrylamide gels using standard methods (Klecha et al. 2006) and transferred onto PVDF membranes. Then the membranes were incubated for $18 \mathrm{~h}$ with appropriate dilutions of primary antibodies: mouse anti-PCNA or rabbit anti-cleaved caspase 3 antibodies (Abcam); rabbit anti-cyclin D1, mouse anti-cyclin D3, and anti-cyclin E1 antibodies (Cell Signaling Technology, Danvers, MA, USA); and rabbit anti-p16/INK4A, mouse anti-p27/Kip1, and mouse anti-p53 antibodies (Santa Cruz Biotechnology). The membranes were then incubated with anti-rabbit (Abcam) or anti-mouse (Santa Cruz Biotechnology) secondary antibodies conjugated to HRP for $1 \mathrm{~h}$. An ECL system (Amersham ECL Prime Western blotting detection reagent; GE Healthcare, Buckinghamshire, UK) was used to detect the proteins. A rabbit anti- $\beta$ actin antibody (Santa Cruz Biotechnology) was used as a control for the protein loaded. Densitometry analysis of the bands was performed using the ImageJ Software (version 5.1, Silk Scientific Corporation, NIH, Bethesda, MA, USA). The densitometry units for the protein bands were normalized to the corresponding $\beta$-actin bands.

\section{Statistical analysis}

The means of the different experimental groups were analyzed for statistical significance using GraphPad PRISM 4.0 Version for Windows (GraphPad Software, Inc., La Jolla, CA, USA); two-way ANOVA followed by Tukey's post hoc analysis was used to assess statistical significance. The differences between the means were considered significant if $P<0.05$. The results are expressed as mean \pm s.E.M. Survival curves were created using the Kaplan-Meier method, and the survival rates were compared using the log-rank test.

\section{Results}

\section{Thyroid status regulates tumor growth}

The progression of the EL4 lymphoma cells growing in vivo in syngeneic mice with different thyroid status was evaluated. The plasma levels of $\mathrm{T}_{3}, \mathrm{~T}_{4}$, and TSH were determined to check the efficacy of the $\mathrm{T}_{4}$ and PTU treatments. Hyperthyroid mice showed high plasma levels of $\mathrm{T}_{3}$ and $\mathrm{T}_{4}$ and low levels of TSH, while hypothyroid mice showed lower $\mathrm{T}_{3}$ and $\mathrm{T}_{4}$ levels, but higher levels of TSH than euthyroid mice (Fig. 1A). After
EL4 cell inoculation, all animals developed solid tumors. Hyperthyroid mice showed a significant increase in EL4 lymphoma growth, while the hypothyroid mice showed no statistically significant differences when compared with the euthyroid controls (Fig. 1B, C, and D). Additionally, Kaplan-Meier survival curves (Fig. 1E) showed a significant reduction in the survival of hyperthyroid mice compared with hypothyroid and euthyroid mice, indicating a worse prognosis. Hyperthyroid mice showed a survival of $50 \%$ at $17.2 \pm 1.4^{*}$ days, while hypothyroid and euthyroid mice showed a survival of $50 \%$ at $22.1 \pm$ 1.5 and $21.3 \pm 1.7$ days respectively $\left({ }^{*} P<0.05\right.$ vs the euthyroid or hypothyroid mice). As the hyperthyroid animals showed increased tumor development compared with control and hypothyroid mice, the kinetics of EL4 cell division were evaluated. For this analysis, EL4 cells were stained with CFSE before inoculation, and the MFI of the CFSE-labeled cells in the tumors was evaluated by flow cytometry, ten days post-inoculation. The EL4 cells growing in hyperthyroid mice exhibited a lower MFI than the tumor cells in control or hypothyroid animals (Fig. $2 \mathrm{~A}$ and $\mathrm{B}$ ). Consistent with these findings, hyperthyroid mice showed an increased rate of cell proliferation when compared with euthyroid and hypothyroid mice (Fig. 2C). No significant differences were observed between the hypothyroid and euthyroid groups. The increase in the cell division rate that was observed in hyperthyroid mice could contribute to the rapid tumor growth and the lower survival of these animals.

\section{Effects of thyroid status on the histological characteristics of the tumor tissue}

The histopathological characteristics of the tumor tissue were examined using sections stained with $\mathrm{H} \& \mathrm{E}$ and Masson's trichrome. Tumor sections from all of the experimental groups showed undifferentiated lymphoma cells with aberrant nuclei and marked anisokaryosis and karyorrhexis, as well as the presence of connective tissue trabeculae and infiltrates in the muscle tissue. The tumors from hyperthyroid mice showed an increased number of mitotic cells, as well as the presence of cystic areas and some levels of necrosis. The tumors from hypothyroid mice exhibited a lower number of mitotic cells and fewer cystic formations, but areas of diffuse hemorrhage and vascular damage with high levels of necrosis were also observed. The absence of necrosis and a low number of cystic formations were found in the tumors from euthyroid mice (Fig. 3A and B). Additionally, intratumoral vascularization in the tumor sections was evaluated using

Published by Bioscientifica Ltd 


\begin{tabular}{|c|c|c|c|}
\hline $\begin{array}{c}\text { Thyroid } \\
\text { status }\end{array}$ & $\begin{array}{c}\mathrm{T}_{3} \\
(\mathrm{ng} / 100 \mathrm{ml})\end{array}$ & $\begin{array}{c}\mathrm{T}_{4} \\
(\mu \mathrm{g} / 100 \mathrm{ml})\end{array}$ & $\begin{array}{c}\mathrm{TSH} \\
(\mathrm{ng} / \mathrm{ml})\end{array}$ \\
\hline Euthyroid & $115.0 \pm 12.5$ & $5.5 \pm 0.7$ & $47.8 \pm 5.4$ \\
\hline Hyperthyroid & $423.0 \pm 47.1^{*}$ & $32.7 \pm 1.8^{*}$ & $<20$ \\
\hline Hypothyroid & $60.6 \pm 10.2^{*}$ & $<1.0$ & $64.2 \pm 6.8^{*}$ \\
\hline
\end{tabular}
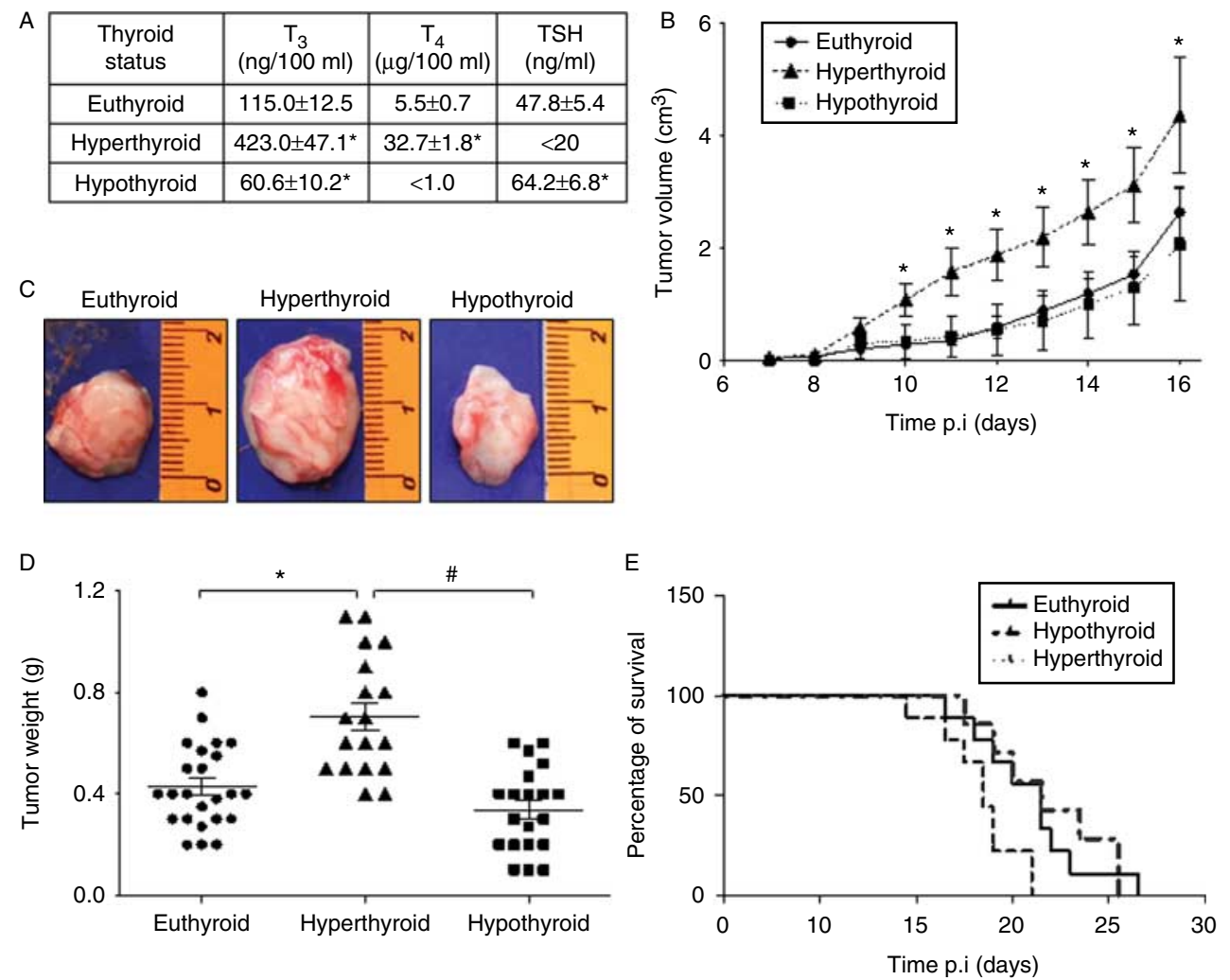

\section{Figure 1}

Effects of thyroid status on tumor progression. The plasma levels of thyroid hormones in euthyroid, hyperthyroid, and hypothyroid mice were determined using ELISA, as described in Materials and methods (A). Euthyroid, hyperthyroid, and hypothyroid mice received subcutaneous inoculations of $3 \times 10^{5} \mathrm{EL} 4$ cells, and the volumes of the resulting solid tumors were measured (B). Representative photographs of the solid tumors grown in mice with different thyroid status 10 days after inoculation are

the Masson's trichrome staining and immunostaining with an anti-CD31 antibody. The tumors from hyperthyroid mice exhibited more vascularization, with large vessels and increased expression of the CD31 (PECAM1) vascular endothelium marker, when compared with those from euthyroid or hypothyroid animals (Fig. 3A and C).

\section{Thyroid status modulates tumor angiogenesis}

Peritumoral angiogenesis was quantified in the three experimental groups 6 days after EL4 cell inoculation, when the tumors were palpable. Hyperthyroid mice displayed an increased number of blood vessels surrounding the tumor tissue (Fig. 3D and E). Additionally, this group showed a higher angiogenesis level in the normal dermal tissue (Fig. 3D and F, right flank). Non-significant differences were found between euthyroid and hypothyroid animals.

shown (C). The tumor tissue weight removed at 10 days post-inoculation was determined (D). Kaplan-Meier survival analysis was performed on the experimental groups that had received subcutaneous inoculations of $3 \times 10^{5} \mathrm{EL} 4$ cells (E). The values are expressed as mean \pm s.E.M. ${ }^{*} P<0.05$ vs corresponding euthyroid mice. ${ }^{\#} P<0.05$ between hyperthyroid and hypothyroid mice. A full colour version of this figure is available at http:// dx.doi.org/10.1530/JOE-14-0159.

\section{Thyroid status alters the balance between proliferation and apoptosis in tumor cells}

The balance between proliferation and apoptosis of $\mathrm{T}$ lymphoma cells in the tumors growing in euthyroid, hyperthyroid, or hypothyroid mice was evaluated. The tumors from hyperthyroid mice expressed high levels of the PCNA marker and cleaved caspase 3 in the nonnecrotic areas of the tumor tissue, as shown by immunohistochemistry analysis (Fig. 4A). The protein levels of both markers were also quantified using western blot analysis. The tumors from hypothyroid and euthyroid mice showed no significant differences in the levels of PCNA or cleaved caspase 3 (Fig. 4B and C). As the increase in the level of PCNA was greater than the increase in cleaved caspase 3 within the tumor sample, we determined the ratio between the two markers. Figure 4D shows that this ratio was increased in hyperthyroid mice when

Published by Bioscientifica Ltd. 




CFSE fluorescence intensity



C

\begin{tabular}{|c|c|}
\hline $\begin{array}{c}\text { Experimental } \\
\text { groups }\end{array}$ & $\begin{array}{c}\text { Cell division } \\
\text { time }\end{array}$ \\
\hline Euthyroid & $40.9 \pm 3.7$ \\
Hyperthyroid & $32.4^{*} \pm 2.9$ \\
Hypothyroid & $43.9 \pm 4.1$ \\
\hline
\end{tabular}

Figure 2

Effects of thyroid status on the rate of tumor cell division. EL4 cells were stained with carboxyfluorescein diacetate succinimidyl ester (CFSE) and were subcutaneously inoculated into euthyroid, hyperthyroid, and hypothyroid mice. Ten days post-inoculation, the tumor tissue was removed, and the CFSE mean fluorescence intensity (MFI) values of the tumor cells were quantified using flow cytometry. Representative histograms of four independent experiments are shown. The histogram corresponding to $T_{0}$ represents the CFSE fluorescence intensity of the EL4 cells before inoculation into the animal models. The MFIs of the EL4 cells grown in euthyroid, hyperthyroid, and hypothyroid mice are indicated in parentheses (A). The MFI of each experimental group is shown in the bar graph as a percentage of the MFI at $T_{0}$ (B). The estimated cell division time is indicated in the table (C). The values are expressed as mean \pm S.E.M. ${ }^{\star} P<0.01$ vs euthyroid mice. A full colour version of this figure is available at http://dx.doi.org/10.1530/JOE-14-0159.

compared with the other two groups. These results could explain the observed differences in tumor growth among the animals with different thyroid status.

\section{Thyroid status modulates the expression of proteins associated with cell cycle progression}

As we found that the thyroid status modulates the rate of cell division, the expression levels of several genes related to the regulation and the promotion of the cell cycle were analyzed in the solid tumors growing in mice with different thyroid status.

The tumors from hyperthyroid mice showed increased cyclin D1, D3, and E1 mRNA levels. We found no differences in the levels of cyclin A, B, and D2 mRNA at this time. The tumors from hypothyroid mice showed no significant differences in the mRNA levels of the cyclins when compared with euthyroid control mice (Fig. 5A). Additionally, we observed increased levels of the cyclin D1 and D3 proteins in the hyperthyroid tumors (Fig. 5B and C). The CDKIs are key regulators of cell cycle progression. Thus, we also evaluated their mRNA expression. Only the expression levels of the $p 16 / \operatorname{Ink} 4 a$ and $p 27 / K i p 1$ genes were modulated by the thyroid status of the animals carrying tumors. The tumors from hypothyroid mice showed increased $p 16 /$ Ink $4 a$ mRNA expression when compared with euthyroid animals and increased p27/Kip1 mRNA expression when compared with euthyroid or hyperthyroid animals (Fig. 6A). Additionally, the increased expression of these proteins was observed only in hypothyroid animals, when compared with hyperthyroid animals, according to the western blot results (Fig. 6C and D). Non-significant differences in the mRNA expression of CDKIs were observed in the solid tumors from hyperthyroid mice compared with euthyroid mice (Fig. 6A). However, a decrease in the protein levels of p27/KIP1 was observed by western blot analysis (Fig. 6C and D).

In the case of the tumor suppressor genes, which protect cells from malignant transformation by inhibiting cell cycle progression, a significant increase in the mRNA expression of $p 53$ was observed in the tumors from hypothyroid mice compared with the tumors from the hyperthyroid group (Fig. 6B). This was accompanied by an increase in its protein expression (Fig. 6C and D). The tumors from hyperthyroid mice showed no significant differences in the mRNA expression of the tumor suppressor genes (Fig. 6B), but a decrease in p53 protein, when compared with euthyroid controls, was observed (Fig. 6C and D).

\section{Discussion}

In this study, despite the controversial results on the effect of thyroid status regulation on tumor growth, we demonstrated that the development of $\mathrm{T}$ cell lymphoma in syngeneic mice is affected by a TH-mediated increase in tumor $\mathrm{T}$ cell proliferation. We showed that hyperthyroid mice developed larger tumors than control or hypothyroid animals, an effect that was impaired by reverting to euthyroid conditions (data

Published by Bioscientifica Ltd 
A

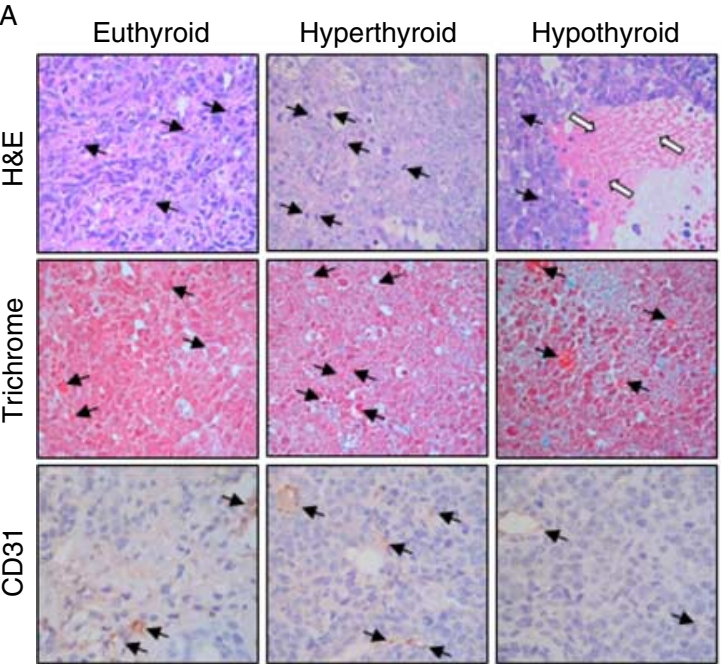

D

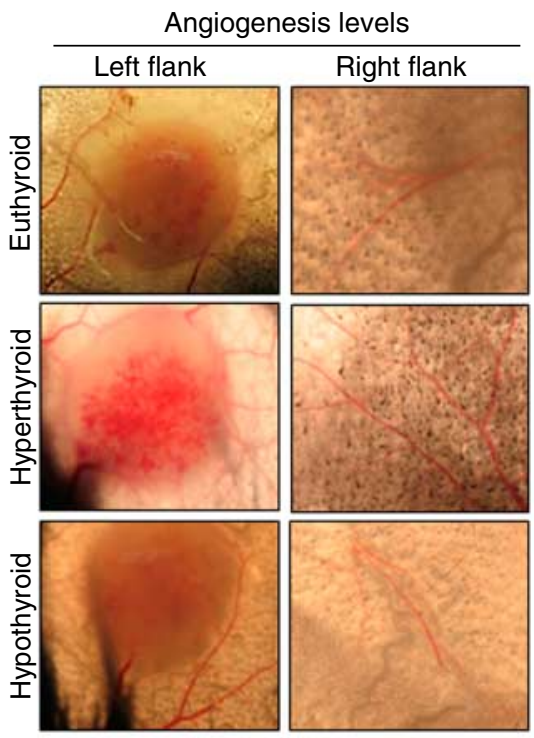

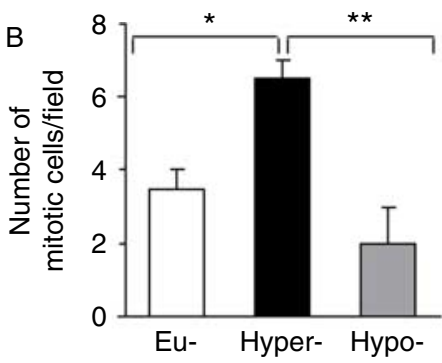

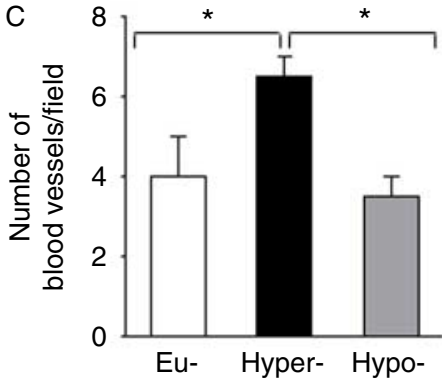

E
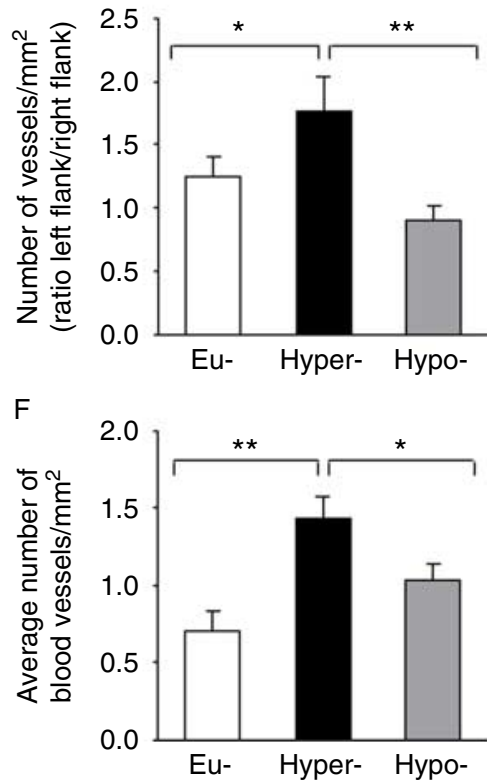

Figure 3

Effects of thyroid status on the histological characteristics of the tumor tissue and tumor angiogenesis. Solid tumors grown in euthyroid, hyperthyroid, and hypothyroid mice were excised 10 days after tumor inoculation. The tumor tissue were fixed, embedded in paraffin, and cut into serial sections using a microtome. Histological characteristics of the tumor tissue were examined in the tissue sections after staining with hematoxylin-eosin (H\&E) and Masson's trichrome. Vascularization in the tissue sections was evaluated using Masson's trichrome and immunostaining with an anti-CD31 antibody. Representative photographs from four independent trials using five animals per group are shown. The black arrows indicate the mitotic cells (H\&E staining), blood vessels (Masson's trichrome), or endothelial cells (CD31+ immunostaining), and the white arrows indicate the hemorrhagic areas (H\&E staining) (A). The number of mitotic cells in the tissue sections stained with H\&E was quantified. Ten random fields from each sample from each experimental group were analyzed (B). The number of blood vessels in the tissue sections stained with Masson's trichrome solution was quantified. Intratumoral vascularity was evaluated by counting the number of blood vessels inside the tumor in ten random fields (C). Angiogenesis was quantified in the solid tumors grown in euthyroid, hyperthyroid, and hypothyroid mice 6 days after inoculation with EL4 cells, as described in Materials and methods. Representative solid tumors fed by blood vessels are shown (left flank). The right flanks of mice without tumor inoculation are shown as controls (D). The number of blood vessels in the tumor tissue area was normalized to the number of vessels in the normal dermal tissue area present in the flank control, which had received an inoculation of sterile PBS solution (E). The average number of blood vessels in the control flank (without tumor) is shown in the bar graph (F). The values are expressed as mean \pm s.E.M. $* * P<0.01$ or $* P<0.05$ vs euthyroid mice or hyperthyroid mice. A full colour version of this figure is available at http://dx.doi.org/10.1530/JOE-14-0159.

Published by Bioscientifica Ltd. 


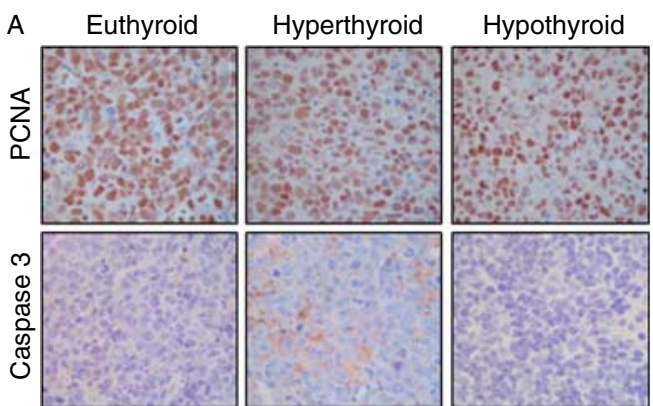

B


Figure 4

Effects of thyroid status on cellular proliferation and apoptosis of the tumor tissue. Tumor tissue sections from euthyroid, hyperthyroid, or hypothyroid mice excised 10 days after EL4 cell inoculation. Lymphoma cell proliferation and apoptosis were determined by immunohistochemistry using PCNA or active caspase 3 antibodies. Representative photographs from four independent experiments using five animals per group are shown (A). PCNA and active caspase 3 expression was evaluated by western blot analysis from the tumor tissue protein extracts. Actin was used as a protein loading control. The results are representative of four independent experiments (B). Densitometric results of the western blot analysis are shown in the bar graph (C). The ratio of PCNA and caspase 3 protein expression is shown (D). The values are expressed as mean \pm s.E.M. ${ }^{*} P<0.05$ or $* * P<0.01$ vs euthyroid mice. A full colour version of this figure is available at http://dx.doi.org/10.1530/JOE-14-0159.

not shown). This was due to an increased cell proliferation rate. In fact, we have already shown that THs have different effects on the murine BW5147 T lymphoma cell line, depending on the time of exposure. THs increased in vitro tumor cell proliferation through the activation of PKC (PRKCZ) and NOS and the increased expression of iNOS (NOS2) when exposed to THs for $<5$ days in culture (Barreiro Arcos et al. 2006). Additionally, we showed that this proliferative activity was mediated by genomic and nongenomic mechanisms involving ERK activation and $\mathrm{TH}$ receptor regulation (Barreiro Arcos et al. 2011). However, prolonged treatment with THs led to cell death by apoptosis

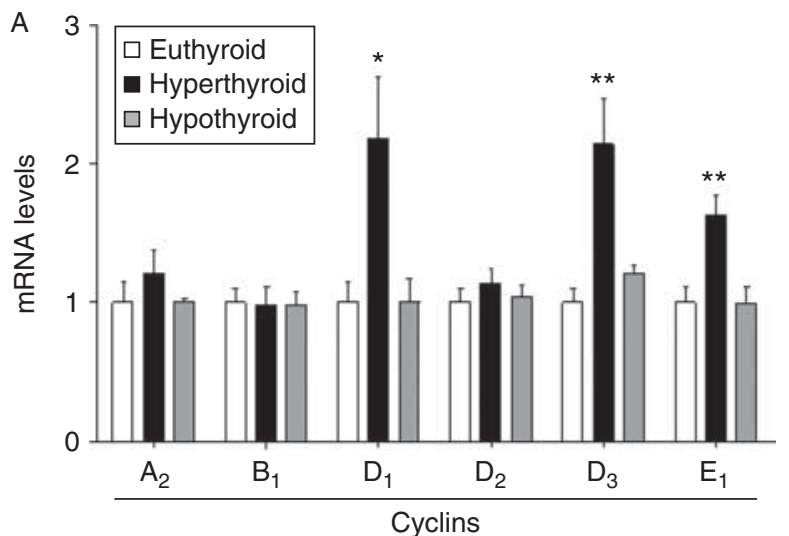

B

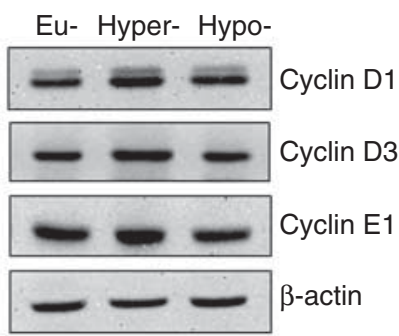

C

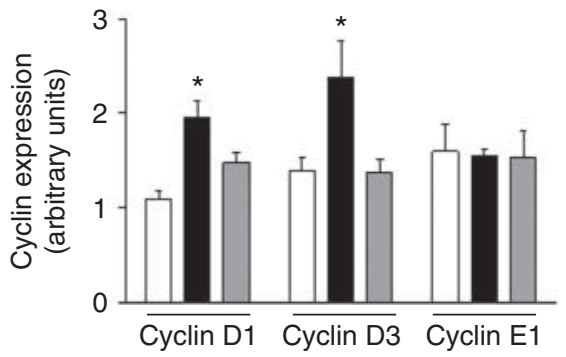

Figure 5

Effects of thyroid status on the expression of cell cycle regulatory proteins. Differential gene expression of the cyclins was observed in the tumor tissues from euthyroid, hyperthyroid, and hypothyroid mice. The mRNA expression of the cyclins was determined using qPCR, and the expression levels were normalized to the expression of the housekeeping gene $\beta$-actin; the $\Delta \Delta C_{t}$ method was used to calculate the fold change (A). The expression of the cyclin proteins was evaluated using western blot analysis. Actin was used as a protein loading control. The results are representative of four independent experiments (B). Densitometric results of the western blot analysis for euthyroid, hyperthyroid, and hypothyroid mice are shown in the bar graph (C). The values are expressed as mean \pm S.E.M. ${ }^{*} P<0.05$ or $* * P<0.01$ vs euthyroid mice. 

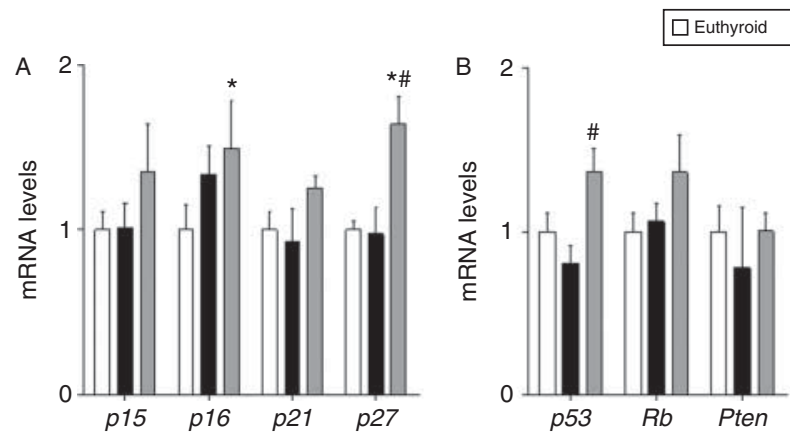

C

D

\section{Figure 6}

Effect of thyroid status on cyclin inhibitors and tumor suppressor proteins. The mRNA expression of the cyclin-dependent kinase (CDK) inhibitors (p15/Ink4b, p16/Ink4a, p21/Cip1, and p27/Kip1) was determined for the tumor tissues from euthyroid, hyperthyroid, and hypothyroid mice using qPCR analysis. Gene expression was normalized to the expression of the $\beta$-actin gene, and the $\Delta \Delta C_{\mathrm{t}}$ method was used to calculate the fold change (A). The mRNA expression of the tumor suppressor genes (p53, Pten, and $R b)$ as determined using qPCR analysis; expression was normalized to the

(Barreiro Arcos et al. 2013). Similar findings were observed in the EL4 cell line (data not shown). Additionally, other in vitro studies in human breast cancer lines (Tang et al. 2004), papillary and follicular thyroid cells (Lin et al. 2007), glioma U-87 MG cells (Lin et al. 2009), and lung cancer cells (Meng et al. 2011) showed that exposure to physiological concentrations of $\mathrm{T}_{3}$ and $\mathrm{T}_{4}$ induced cell proliferation through the activation of ERK1/2.

Moreover, tumor-bearing hyperthyroid mice exhibited a decreased survival rate. The increased cell division rate that was observed in the tumors from hyperthyroid mice could contribute to the rapid tumor growth and the reduced survival of these animals. It is unlikely that animals died as a result of the effects of hyperthyroidism, as hyperthyroid animals without tumors lived significantly longer than the tumor-bearing animals. However, we cannot rule out the possibility that the stress generated by tumor development could negatively influence the survival of hyperthyroid animals (Frick et al. 2009a,b).

No differences were observed between the tumors grown in euthyroid and hypothyroid mice.

The balance between proliferation and apoptosis of tumor cells is considered to be an indicator of tumor growth; therefore, we analyzed these parameters in our animal models. An increased number of cells expressing the PCNA cell proliferation marker and active caspase 3 were found in the tumors from hyperthyroid animals when compared with the controls, and the ratio between the levels of these proteins was also higher in hyperthyroid mice. Additionally, we observed a significant increase in the number of mitotic cells in the H\&E-stained tissue expression of the $\beta$-actin gene, and the $\Delta \Delta C_{t}$ method was used to calculate the fold change (B). Protein expression of the Cdk inhibitors and the tumor suppressor proteins was analyzed using western blot analysis. Actin was used as a protein loading control. The results are representative of four independent experiments (C). Densitometric results of the western blot analysis are shown in the bar graph (D). The values are expressed as mean \pm s.E.M. ${ }^{*} P<0.05$ vs euthyroid animals; ${ }^{\#} P<0.05$ or ${ }^{\# \#} P<0.01$ vs hyperthyroid animals.

sections of the hyperthyroid tumors, as well as localized phenomena of apoptosis that could be observed as cystic areas without cellular content. This last observation could be explained because the high speed of cell proliferation may cause insufficient supply of nutrients and oxygen to the tumor tissue inducing apoptotic areas. Both phenomena occur together, but our results indicate that the proliferative effect is stronger than the apoptotic action, which is in agreement with the increased tumor growth observed in this group.

Neovascularization is an essential process for the survival of tumor cells and tumor growth. We therefore examined peritumoral and intratumoral angiogenesis in the tumors from euthyroid, hyperthyroid, and hypothyroid mice. Peritumoral angiogenesis was quantified in the tumors grown in our experimental models 6 days after EL4 cell inoculation, when the tumor volume was only a few millimeters. The tumors from hyperthyroid mice showed a greater irrigation of blood vessels than the tumors from euthyroid or hypothyroid animals. Additionally, hyperthyroid mice displayed an increased number of blood vessels in the contralateral flank, which has not received an inoculation of tumor cells. It is noteworthy that hypothyroid mice showed higher levels of necrosis in their tumors than the other studied groups, despite having levels of angiogenesis similar to those observed in euthyroid animals. Similar results were obtained by Martínez-Iglesias et al. (2009) demonstrating that the reduced tumor volume in hypothyroid hosts was correlated with a lower proliferation rate of the tumors, which was also accompanied by enlargement of the necrotic area

Published by Bioscientifica Ltd. 
of the tumors. This is probably a result of TH deficiency. In fact, THs are necessary growth factors involved in T cell lymphoma proliferative and survival signals (Barreiro Arcos et al. 2006, 2011), hence the lack of THs would induce cell death signaling that leads to the formation of the necrotic areas observed in these tumors.

Intratumoral vascularity was evaluated by counting the blood vessels inside the tumor 10 days after inoculation with the tumor cells. The tumor tissue from the hyperthyroid animals showed a larger number of endothelial cells $\left(\mathrm{CD} 31^{+}\right)$, which was in agreement with the increased number of blood vessels shown by Masson's trichrome staining. Hypothyroid mice displayed similar levels of intratumoral and peritumoral angiogenesis to euthyroid controls. Our results are supported by numerous works that indicate the involvement of the THs in the modulation of angiogenesis. Patients with Grave's disease have high serum levels of angiogenic molecules, which are significantly decreased after treatment with antithyroid drugs (Figueroa-Vega et al. 2009). Additionally, patients with Grave's disease exhibit an increased microvessel density (Tseleni-Balafouta et al. 2006) and serum levels of angiogenic vascular endothelial growth factor (Iitaka et al. 1998).

We showed that the hyperthyroid state induces tumor growth by accelerating the process of cell division. There is evidence that the THs modulate the progression of the cell cycle through the regulation of cell cycle regulatory proteins (Woodmansee et al. 2006). We observed that the levels of cyclins D1 and D3 were increased in the tumors grown in the hyperthyroid animals. Increased cyclin D1, which regulates the entry into the G1 phase of the cell cycle, has been widely linked to the regulation of the cell cycle by THs in various cell types (Ledda-Columbano et al. 2006, Verga Falzacappa et al. 2012, Zhang et al. 2012). Many lines of evidence have indicated that cyclins D1 and D3 are involved in T-cell lymphomagenesis and are important molecular markers of oncogenic potential in T cell lymphomas (Teramoto et al. 1999, Cheng et al. 2008). Furthermore, cyclin D3 overexpression is associated with a higher proliferation rate, as well as with lower p27/KIP1 and altered p53 expression (Møller et al. 2001). The positive regulation of cyclins D1 and D3 has been shown to be associated with a poor prognosis in patients with lymphoma (Zukerberg et al. 1995, Kanavaros et al. 2001, Mao et al. 2006). Cyclin E1 is a key mediator of T-cell lymphomagenesis and regulates the transition between G1 and S phases (Hosokawa et al. 1995, Karsunky et al. 1999, Geisen et al. 2003, Kang-Decker et al. 2004); however, we observed an increase only in the mRNA expression of cyclin $\mathrm{E}$ in hyperthyroid animals, but we cannot rule out an increment in its protein levels at other time points. Hypothyroidism does not affect the expression pattern of the cyclins, as the cell division speed and tumor growth were similar to those of the tumors grown in the euthyroid animals.

Results described in previous reports have indicated that the INK4 family is altered in lymphoma (Baur et al. 1999, Gallardo et al. 2004, Nagasawa et al. 2006). We observed an increase in the mRNA and protein levels of p16/INK4A in the tumors from hypothyroid mice compared with those from hyperthyroid mice, but no significant differences were observed in p15/INK4B (CDKN2B) expression. The expression levels of p21/CIP1 (SLC12A9/CDKN1A) were not modulated by thyroid status, even though it has been suggested that this protein is involved in the development of T cell lymphoma (Kanavaros et al. 2001), but we observed a decreased expression of p27/KIP1 in the tumors from hyperthyroid animals compared with those from hypothyroid animals, which is in agreement with several lines of experimental evidence. In this regard, Cheng et al. (2008) found that p27/KIP1 deficiency in transgenic mice leads to T-cell hyperplasia and the development of spontaneous T lymphomas, and Geisen et al. (2003) showed that the reduction in $\mathrm{p} 27 / \mathrm{KIP} 1$ expression is involved in $\mathrm{T}$ cell lymphomagenesis.

Additionally, we evaluated the expression of the PTEN, RB1, and p53 tumor suppressor genes, whose expression levels are often dysregulated in T cell lymphomas (Kanavaros et al. 2001, Møller et al. 2002, Mao et al. 2006). We only observed a decrease in the expression of p53 in the tumors from hyperthyroid animals compared with those from hypothyroid or euthyroid animals, and this result was anticipated due to its key role in hematological malignancies (Kanavaros et al. 2001, Møller et al. 2002). The decreased expression of the p16/INK4A, p27/KIP1, and p53 proteins in the tumors from hyperthyroid mice could facilitate cell cycle progression and contribute to tumor growth.

The results described in this work are in agreement with in vivo studies investigating the modulation of cell cycle regulators in other physiological, non-neoplastic processes. Alisi et al. (2005) demonstrated that hyperthyroidism increased the expression of cyclins D1, E, and $A$ and decreased the expression of p16/INK4A and p27/KIP1 in a rat model of liver regeneration; this study also showed that hypothyroidism resulted in the reduced expression of these cyclins, as well as the increased expression of p16/INK4A, p27/KIP1, and p53.

Based on these results, we conclude that thyroid status can modulate $\mathrm{T}$ lymphoma EL4 growth through the regulation of cell cycle protein expression, which includes

Published by Bioscientifica Ltd 
the cyclins, CDKIs, and tumor suppressor genes and through the up-regulation of angiogenesis. These results will contribute to a better understanding of the actions of THs during tumor development.

\section{Declaration of interest}

The authors declare that there is no conflict of interest that could be perceived as prejudicing the impartiality of the research reported.

\section{Funding}

This work was supported by the Consejo Nacional de Investigaciones Científicas y Técnicas (CONICET), Proyectos de Investigación Plurianuales (PIP)-CONICET No. 00275, the Agencia Nacional para la Promoción Científica y Técnica, Proyectos de Investigación Científica y Tecnológica (PICT) 2008 No. 1858 and PICT Raíces 2012 No. 1328, and the Secretaría de Ciencia y Técnica Universidad de Buenos Aires, (UBACYT) No. 20020100100291.

\section{Acknowledgements}

The authors wish to thank Mrs María Rosa Gonzalez Murano for her excellent technical assistance.

\section{References}

Alisi A, Demori I, Spagnuolo S, Pierantozzi E, Fugassa E \& Leoni S 2005 Thyroid status affects rat liver regeneration after partial hepatectomy by regulating cell cycle and apoptosis. Cellular Physiology and Biochemistry 15 69-76. (doi:10.1159/000083639)

Angelousi AG, Anagnostou VK, Stamatakos MK, Georgiopoulos GA \& Kontzoglou KC 2012 Primary HT and risk for breast cancer: a systematic review and meta-analysis. European Journal of Endocrinology 166 373-381. (doi:10.1530/EJE-11-0838)

Ballock RT, Zhou X, Mink LM, Chen DH, Mita BC \& Stewart MC 2000 Expression of cyclin-dependent kinase inhibitors in epiphyseal chondrocytes induced to terminally differentiate with thyroid hormone. Endocrinology 141 4552-4557. (doi:10.1210/endo.141.12.7839)

Barreiro Arcos ML, Gorelik G, Klecha A, Genaro AM \& Cremaschi GA 2006 Thyroid hormones increase inducible nitric oxide synthase gene expression downstream from PKC- $\zeta$ in murine tumor T lymphocytes. American Journal of Physiology. Cell Physiology 291 327-336. (doi:10.1152/ajpcell.00316.2005)

Barreiro Arcos ML, Sterle H, Paulazo MA, Valli E, Klecha AJ, Isse B, Pellizas CG, Farías RN \& Cremaschi GA 2011 Cooperative nongenomic and genomic actions on thyroid hormone mediated-modulation of $\mathrm{T}$ cell proliferation involve up-regulation of thyroid hormone receptor and inducible nitric oxide synthase expression. Journal of Cellular Physiology 226 3208-3218. (doi:10.1002/jcp.22681)

Barreiro Arcos ML, Sterle HA, Vercelli C, Valli E, Cayrol MF, Klecha AJ, Paulazo MA, Diaz Flaqué MC, Franchi AM \& Cremaschi GA 2013 Induction of apoptosis in T lymphoma cells by long-term treatment with thyroxine involves PKC $\zeta$ nitration by nitric oxide synthase. Apoptosis 18 1376-1390. (doi:10.1007/s10495-013-0869-8)

Baur AS, Shaw P, Burri N, Delacrétaz F, Bosman FT \& Chaubert P 1999 Frequent methylation silencing of $p 15^{I N K 4 b}$ (MTS2) and $p 16^{I N K 4 a}$ (MTS1) in B cell and T-cell lymphomas. Blood 94 1773-1781.

Chattergoon NN, Giraud GD \& Thornburg KL 2007 Thyroid hormone inhibits proliferation of fetal cardiac myocytes in vitro. Journal of Endocrinology 192 R1-R8. (doi:10.1677/JOE-06-0114)
Cheng N, Van de Wetering CI \& Knudson CM 2008 p27 deficiency cooperates with Bcl-2 but not Bax to promote T-cell lymphoma. PLoS ONE 3 e1911. (doi:10.1371/journal.pone.0001911)

Cheng SY, Leonard LJ \& Davis PJ 2010 Molecular aspects of thyroid hormone actions. Endocrine Reviews 31 139-170. (doi:10.1210/er.2009-0007)

Cristofanilli M, Yamamura Y, Kau SW, Bevers T, Strom S, Patangan M, Hsu L, Krishnamurthy S, Theriault RL \& Hortobagyi GN 2005 Thyroid hormone and breast carcinoma. Primary hypothyroidism is associated with a reduced incidence of primary breast carcinoma. Cancer $\mathbf{1 0 3}$ 1122-1128. (doi:10.1002/cncr.20881)

Ferrando M, Gueron G, Elguero B, Giudice J, Salles A, Leskow FC, JaresErijman EA, Colombo L, Meiss R, Navone N et al. 2011 Heme oxygenase 1 (HO-1) challenges the angiogenic switch in prostate cancer. Angiogenesis 14 467-479. (doi:10.1007/s10456-011-9230-4)

Figueroa-Vega N, Sanz-Cameno P, Moreno-Otero R, Sánchez-Madrid F, González-Amaro R \& Marazuela M 2009 Serum levels of angiogenic molecules in autoimmune thyroid diseases and their correlation with laboratory and clinical features. Journal of Clinical Endocrinology and Metabolism 94 1145-1153. (doi:10.1210/jc.2008-1571)

Frick LR, Arcos ML, Rapanelli M, Zappia MP, Brocco M, Mongini C, Genaro AM \& Cremaschi GA 2009a Chronic restraint stress impairs T-cell immunity and promotes tumor progression in mice. Stress 12 134-143. (doi:10.1080/10253890802137437)

Frick LR, Rapanelli M, Bussmann U, Klecha AJ, Barreiro Arcos ML, Genaro AM \& Cremaschi GA $2009 b$ Involvement of thyroid hormones in the alterations of T-cell immunity and tumor progression induced by chronic stress. Biological Psychiatry 65 935-942. (doi:10.1016/j.biopsych.2008.12.013)

Frick LR, Rapanelli M, Arcos ML, Cremaschi GA \& Genaro AM 2011 Oral administration of fluoxetine alters the proliferation/apoptosis balance of lymphoma cells and up-regulates T cell immunity in tumor-bearing mice. European Journal of Pharmacology 659 265-272. (doi:10.1016/ j.ejphar.2011.03.037)

Gallardo F, Esteller M, Pujol RM, Costa C, Estrach T \& Servitje O 2004 Methylation status of the p15, p16 and MGMT promoter genes in primary cutaneous T-cell lymphomas. Haematologica 89 1401-1403.

Geisen C, Karsunky H, Yücel R \& Möröy T 2003 Loss of p $27^{\text {Kip1 }}$ cooperates with cyclin E in T-cell lymphomagenesis. Oncogene 22 1724-1729. (doi:10.1038/sj.onc.1206340)

Guernsey DL, Ong A \& Borek C 1980 Thyroid hormone modulation of $\mathrm{X}$-ray induced in vitro neoplastic transformation. Nature $\mathbf{2 8 8} 591-592$. (doi:10.1038/288591a0)

Hercbergs AH, Ashur-Fabian O \& Garfield D 2010 Thyroid hormones and cancer: clinical studies of hypothyroidism in oncology. Current Opinion in Endocrinology, Diabetes, and Obesity 17 432-436. (doi:10.1097/ MED.0b013e32833d9710)

Hosokawa Y, Yang M, Kaneko S, Tanaka M \& Nakashima K 1995 Synergistic gene expressions of cyclin E, cdk2, cdk5 and E2F-1 during the prolactininduced $\mathrm{G} 1 / \mathrm{S}$ transition in rat $\mathrm{Nb} 2$ pre-T lymphoma cells. Biochemistry and Molecular Biology International 37 393-399.

Iitaka M, Miura S, Yamanaka K, Kawasaki S, Kitahama S, Kawakami Y, Kakinuma S, Oosuga I, Wada S \& Katayama S 1998 Increased serum vascular endothelial growth factor levels and intrathyroidal vascular area in patients with Graves' disease and Hashimoto's thyroiditis. Journal of Clinical Endocrinology and Metabolism 83 3908-3912. (doi:10. 1210/jcem.83.11.5281)

Kanavaros P, Bai M, Stefanaki K, Poussias G, Rontogianni D, Zioga E, Gorgoulis V \& Agnantis NJ 2001 Immunohistochemical expression of the p53,mdm2, p21/Waf-1, Rb, p16, Ki67, cyclin D1, cyclin A and cyclin B1 proteins and apoptotic index in T-cell lymphomas. Histology and Histopathology 16 377-386.

Kang-Decker N, Tong C, Boussouar F, Baker DJ, Xu W, Leontovich AA, Taylor WR, Brindle PK \& Van Deursen JM 2004 Loss of CBP causes T cell lymphomagenesis in synergy with $\mathrm{p} 27^{\mathrm{Kip} 1}$ insufficiency. Cancer Cell 5 177-189. (doi:10.1016/S1535-6108(04)00022-4) 
Karsunky H, Geisen C, Schmidt T, Haas K, Zevnik B, Gau E \& Möröy T 1999 Oncogenic potential of cyclin $\mathrm{E}$ in T-cell lymphomagenesis in transgenic mice: evidence for cooperation between cyclin $\mathrm{E}$ and Ras but not Myc. Oncogene 18 7816-7824. (doi:10.1038/sj.onc.1203205)

Kilkenny C, Browne WJ, Cuthill IC, Emerson M \& Altman DG 2010 Improving bioscience research reporting: the ARRIVE Guidelines for reporting animal research. PLoS Biology 8 e1000412. (doi:10.1371/ journal.pbio.1000412)

Klecha AJ, Barreiro Arcos ML, Genaro AM, Gorelik G, Silberman DM, Caro R $\&$ Cremaschi GA 2005 Different mitogen-mediated $\beta$-adrenergic receptor modulation in murine $\mathrm{T}$ lymphocytes depending on the thyroid status. Neuroimmunomodulation 12 92-99. (doi:10.1159/ 000083581)

Klecha AJ, Genaro AM, Gorelik G, Barreiro Arcos ML, Silberman DM, Schuman M, Garcia SI, Pirola C \& Cremaschi GA 2006 Integrative study of hypothalamus-pituitary-thyroid-immune system interaction: thyroid hormone-mediated modulation of lymphocyte activity through the protein kinase C signaling pathway. Journal of Endocrinology 189 45-55. (doi:10.1677/joe.1.06137)

Kucharz EJ, Kotulska A, Kopeć M, Stawiarska-Pieta B \& Pieczyrak R 2003 Serum level of the circulating angiogenesis inhibitor endostatin in patients with hyperthyroidism or hypothyroidism. Wiener Klinische Wochenschrift 115 179-181. (doi:10.1007/BF03040306)

Ledda-Columbano GM, Perra A, Pibiri M, Molotzu F \& Columbano A 2005 Induction of pancreatic acinar cell proliferation by thyroid hormone. Journal of Endocrinology 185 393-399. (doi:10.1677/joe.1.06110)

Ledda-Columbano GM, Molotzu F, Pibiri M, Cossu C, Perra A \& Columbano A 2006 Thyroid hormone induces cyclin D1 nuclear translocation and DNA synthesis in adult rat cardiomyocytes. FASEB Journal 20 87-94. (doi:10.1096/fj.05-4202com)

Lin HY, Tang HY, Shih A, Keating T, Cao G, Davis PJ \& Davis FB 2007 Thyroid hormone is a MAPK-dependent growth factor for thyroid cancer cells and is anti-apoptotic. Steroids 72 180-187. (doi:10.1016/j. steroids.2006.11.014)

Lin HY, Sun M, Tang HY, Lin C, Luidens MK, Mousa SA, Incerpi S, Drusano GL, Davis FB \& Davis PJ 2009 L-thyroxine vs. 3,5,3'-triiodo-L-thyronine and cell proliferation: activation of mitogen-activated protein kinase and phosphatidylinositol 3-kinase. American Journal of Physiology. Cell Physiology 296 980-991. (doi:10.1152/ajpcell.00305.2008)

Livak KJ \& Schmittgen TD 2001 Analysis of relative gene expression data using real-time quantitative PCR and the $2^{-\Delta \Delta \mathrm{C}_{\mathrm{T}}}$ method. Methods 25 402-408. (doi:10.1006/meth.2001.1262)

Lyons AB 1999 Divided we stand: tracking cell proliferation with carboxyfluorescein diacetate succinimidyl ester. Immunology and Cell Biology 77 509-515. (doi:10.1046/j.1440-1711.1999.00864.x)

Mao X, Orchard G, Vonderheid EC, Nowell PC, Bagot M, Bensussan A, Russell-Jones R, Young BD \& Whittaker SJ 2006 Heterogeneous abnormalities of CCND1 and RB1 in primary cutaneous T-cell lymphomas suggesting impaired cell cycle control in disease pathogenesis. Journal of Investigative Dermatology 126 1388-1395. (doi:10. 1038/sj.jid.5700224)

Martínez-Iglesias O, García-Silva S, Regadera J \& Aranda A 2009 Hypothyroidism enhances tumor invasiveness and metastasis development. PLoS ONE 4 e6428. (doi:10.1371/journal.pone.0006428)

Massari NA, Medina VA, Cricco GP, Martinel Lamas DJ, Sambuco L, Pagotto R, Ventura C, Ciraolo PJ, Pignataro O, Bergoc RM et al. 2013 Antitumor activity of histamine and clozapine in a mouse experimental model of human melanoma. Journal of Dermatological Science 72 252-262. (doi:10.1016/j.jdermsci.2013.07.012)

Meng R, Tang HY, Westfall J, London D, Cao JH, Mousa SA, Luidens M, Hercbergs A, Davis FB, Davis PJ et al. 2011 Crosstalk between integrin $\alpha v \beta 3$ and estrogen receptor- $\alpha$ is involved in thyroid hormone-induced proliferation in human lung carcinoma cells. PLOS ONE 6 e27547. (doi:10.1371/journal.pone.0027547)

Mihara S, Suzuki N, Wakisaka S, Sekita N, Hoshino T \& Sakane T 1999 Effects of thyroid hormones on apoptotic cell death of human lymphocytes. Journal of Clinical Endocrinology and Metabolism 84 1378-1385. (doi:10.1210/jcem.84.4.5598)

Møller MB, Nielsen O \& Pedersen NT 2001 Cyclin D3 expression in nonHodgkin lymphoma. Correlation with other cell cycle regulators and clinical features. American Journal of Clinical Pathology 115 404-412. (doi:10.1309/8KF0-0Y0C-2F4L-UHXL)

Møller MB, Nielsen O \& Pedersen NT 2002 Frequent alteration of MDM2 and p53 in the molecular progression of recurring non-Hodgkin's lymphoma. Histopathology 41 322-330. (doi:10.1046/j.1365-2559. 2002.01506.x)

Nagasawa T, Zhang Q, Raghunath PN, Wong HY, El-Salem M, Szallasi A, Marzec M, Gimotty P, Rook AH, Vonderheid EC et al. 2006 Multi-gene epigenetic silencing of tumor suppressor genes in T-cell lymphoma cells; delayed expression of the p16 protein upon reversal of the silencing. Leukemia Research 30 303-312. (doi:10.1016/j.leukres.2005.08.012)

Reddy A, Dash C, Leerapun A, Mettler TA, Stadheim LM, Lazaridis KN, Roberts RO \& Roberts LR 2007 Hypothyroidism: a possible risk factor for liver cancer in patients with no known underlying cause of liver disease. Clinical Gastroenterology and Hepatology 5 118-123. (doi:10. 1016/j.cgh.2006.07.011)

Rennert G, Rennert HS, Pinchev M \& Gruber SB 2010 A case-control study of levothyroxine and the risk of colorectal cancer. Journal of the National Cancer Institute 102 568-572. (doi:10.1093/jnci/djq042)

Tang HY, Lin HY, Zhang S, Davis FB \& Davis PJ 2004 Thyroid hormone causes mitogen-activated protein kinase-dependent phosphorylation of the nuclear estrogen receptor. Endocrinology 145 3265-3272. (doi:10. 1210/en.2004-0308)

Teramoto N, Pokrovskaja K, Szekely L, Polack A, Yoshino T, Akagi T \& Klein G 1999 Expression of cyclin D2 and D3 in lymphoid lesions. International Journal of Cancer 81 543-850. (doi:10.1002/(SICI)10970215(19990517)81:4\%3C;543::AID-IJC7\%3E;3.0.CO;2-3)

Toms SA, Hercbergs A, Liu J, Kondo S, Haqqi T, Casey G, Iwasaki K, Barnett GH \& Barna BP 1998 Antagonist effect of insulin-like growth factor I on protein kinase inhibitor-mediated apoptosis in human glioblastoma cells in association with bcl-2 and bcl-xL. Journal of Neurosurgery $\mathbf{8 8}$ 884-889. (doi:10.3171/jns.1998.88.5.0884)

Tseleni-Balafouta S, Kavantzas N, Balafoutas D \& Patsouris E 2006 Comparative study of angiogenesis in thyroid glands with Graves disease and Hashimoto's thyroiditis. Applied Immunohistochemistry \& Molecular Morphology 14 203-207. (doi:10.1097/01.pai.0000174262.33385.5e)

Verga Falzacappa C, Timperi E, Bucci B, Amendola D, Piergrossi P, D'Amico D, Santaguida MG, Centanni M \& Misiti S $2012 \mathrm{~T}_{3}$ preserves ovarian granulosa cells from chemotherapy-induced apoptosis. Journal of Endocrinology 215 281-289. (doi:10.1530/JOE-12-0153)

Woodmansee WW, Kerr JM, Tucker EA, Mitchell JR, Haakinson DJ, Gordon DF, Ridgway EC \& Wood WM 2006 The proliferative status of thyrotropes is dependent on modulation of specific cell cycle regulators by thyroid hormone. Endocrinology 147 272-282. (doi:10.1210/en. 2005-1013)

Zhang B, Zhang A, Zhou X, Webb P, He W \& Xia X 2012 Thyroid hormone analogue stimulates keratinocyte proliferation but inhibits cell differentiation in epidermis. International Journal of Immunopathology and Pharmacology 25 859-869.

Zukerberg LR, Yang WI, Arnold A \& Harris NL 1995 Cyclin D1 expression in non-Hodgkin's lymphomas. Detection by immunohistochemistry. American Journal of Clinical Pathology 103 756-760.

Received in final form 29 May 2014

Accepted 11 June 2014

Accepted Preprint published online 13 June 2014 http://joe.endocrinology-journals.org DOI: 10.1530/JOE-14-0159
() 2014 Society for Endocrinology Printed in Great Britain 